\title{
Pengaruh Faktor Lingkungan terhadap Keberlanjutan Usahatani Alpukat (Persea americana)
}

\author{
Muhlisin $^{a}$, Setiawan Bambang Mulyatno ${ }^{\mathbf{b}}$, Ekowati Titik \\ ${ }^{a}$ Fakultas Peternakan dan Pertanian, Universitas Diponegoro,Semarang, Indonesia, email: snapzsin@gmail.com \\ ${ }^{b}$ Fakultas Peternakan dan Pertanian, Universitas Diponegoro,Semarang, Indonesia \\ ${ }^{c}$ Fakultas Peternakan dan Pertanian, Universitas Diponegoro Semarang, Indonesia
}

\section{Article Info}

Article history:

Received 20 February 2021

Received in revised from 25 February 2021

Accepted 18 March 2021

DOI:

https://doi.org/10.32938/ag.v6i2.1317

Keywords:

Avocado

Path Analysis

Sustainable

Environment

\begin{abstract}
Abstrak
The sustainability of avocado fruit farming in Indonesia needs to be considered, this is because avocados have a large market potential in Indonesia. One of the factors in the sustainability of farming is the environment, where environmental factors consist of several indicators. The purpose of this study was to analyze the influence of environmental factors in influencing the sustainability of avocado farming. The method of determining the sample of farmers using stratified random sampling and obtained 125 respondents. Data analysis used path analysis with AMOS 24.0 software. The results of the path analysis show that environmental factors have a direct effect on sustainability with a standardized regression coefficient of 0.290. The forming of environmental factor variables consists of five indicators, including weeding and cleaning garbage, pruning branches, applying insecticides, applying fertilizers, and harvesting. The coefficient value is obtained from the fertilizer application indicator $(x 11=$ $0.990)$; giving insecticides (x12 = 1.050); pruning branches $(x 13=1.080)$; weeding and clearing garbage (x14 = 1.050; , and harvesting ( $x 15=1.000)$. Based on these data, it can be concluded that all indicators that form environmental variables have an effect on the sustainability of avocado farming.
\end{abstract}

\section{Pendahuluan}

Sektor pertanian mempunyai peranan strategis sebagai penyedia bahan pangan, pemasok bahan baku, pembuka lapangan kerja dan sumber devisa negara. Kementan (2019) menyebutkan kontribusi sektor pertanian terhadap perekonomian nasional semakin nyata, dalam kurun waktu 2013 - 2018, PDB sektor pertanian secara konsisten menunjukkan tren positif. Tahun 2019 PDB sektor pertanian tumbuh Rp 40,4 triliun atau 19,67\% (naik dari Rp 205,3 triliun menjadi Rp 245,7 triliun) bahkan tumbuh paling tinggi dibandingkan sektor lainnya.

Tahun 2018 produksi buah-buahan mencapai 21,5 juta ton, sayuran 13 juta ton, tanaman hias 870 juta tangkai, dan tanaman obat mencapai 676 ribu ton. Kinerja volume ekspor hortikultura pada 2018 mencapai 435 ribu ton, naik 10,36 persen dibanding 2017 sebanyak 394 ribu ton. Buah-buahan yang berperan dalam peningkatan ekspor tersebut salah satunya adalah alpukat. Produksi buah nasional mencapai 20.830 .471 ton, dan komoditi alpukat ini memberikan kontribusi sebesar 410.094 ton (Kementan, 2019). Produksi buah alpukat di Kabupaten Kendal pada tahun 2019 mencapai 21.892 kwintal, memberikan kontribusi sebesar $1,97 \%$ terhadap total produksi buah di Kabupaten Kendal dengan nilai 1.111.269 ton. (BPS Kendal, 2020).

Produksi dari alpukat ini akan terus berlangsung selama keberlanjutan dari usahatani ini dipertahankan. Keberlanjutan usahatani tersebut salahsatunya dipengaruhi oleh lingkungan, dimana faktor lingkungan ini terdiri dari beberapa indikator. Aspek lingkungan adalah aspek untuk mengetahui dampak yang ditimbulkan jika suatu investasi atau usaha jadi dilakukan, baik dampak negatif maupun dampak positif. Dampak yang timbul ada yang langsung mempengaruhi pada kegiatan usaha yang dilakukan sekarang, atau baru kelihatan di masa yang akan datang (Sutrisno, 2013).

Aspek lingkungan menganalisis kesesuaian lingkungan sekitar (baik lingkungan operasional, lingkungan dekat, dan lingkungan jauh) dengan ide bisnis yang akan dijalankan. Aspek dampak bisnis bagi lingkungan juga dianalisis. Suatu ide bisnis dinyatakan layak berdasarkan aspek lingkungan jika kondisi lingkungan sesuai dengan kebutuhan ide bisnis dan ide bisnis tersebut mampu memberikan manfaat yang lebih besar dibandingkan dampak negatifnya (Purnomo et al., 2017).

Analisis aspek lingkungan dilakukan untuk menjawab manfaat aspek lingkungan bagi usahatani. Suatu ide usaha dinyatakan layak berdasarkan aspek lingkungan sesuai dengan kebutuhan ide usaha dan ide usaha tersebut mampu memberikan manfaat yang lebih besar dibandingkan dampak negatifnya di wilayah tersebut. Berdasarkan uraian tersebut, maka permasalahan yang perlu dikaji dalam penelitian ini adalah bagaimana pengaruh faktor lingkungan terhadap keberlanjutan usahatani alpukat di Kecamatan Limbangan Kabupaten Kendal. 


\section{Metode}

Lokasi penelitian berada di Kecamatan Limbangan Kabupaten Kendal Provinsi Jawa Tengah. Penentuan lokasi penelitian dilakukan secara sengaja (purposive), dikarenakan Kecamatan Limbangan merupakan kecamatan di Kabupaten Kendal yang menjadi sentra produksi alpukat. Dinas Pertanian dan Pangan Kabupaten Kendal menyebutkan hasil produksi buah alpukat pada Tahun 2019 Kecamatan Limbangan menempati kecamatan dengan produksi tertinggi. Produksi sebesar 12.220 kwintal dihasilkan di kecamatan tersebut dari total produksi 21.892 kwintal. Metode pengambilan sampel secara cluster dengan kriteria meliputi umur responden minimal 17 tahun, mempunyai pohon alpukat yang sudah berproduksi minimal 2 pohon, dan sudah pernah melakukan penjualan dalam satu tahun terakhir, dengan jumlah responden sebanyak 125 petani. Penelitan dilaksanakan selama satu bulan yaitu di bulan November 2020 dengan menggunakan data primer dan sekunder. Data Primer diperoleh dengan wawancara langsung dari petani alpukat. Data sekunder diperoleh dari instansi pemerintah atau lembaga terkait dengan mencatat secara langsung berupa data dari Dinas Pertanian dan Perkebunan Provinsi Jawa Tengah, maupun dari Badan Pusat Statistik Kabupaten Kendal.

Analisis yang digunakan dalam penelitian ini menggunakan analisis jalur (Path analysis) dengan software AMOS 24.0. Analisis jalur merupakan perluasan dari analisis linear berganda, yaitu penggunaan analisis regresi untuk menaksir hubungan kausalitas antar variabel (model kausal) yang telah ditetapkan (Ghozali, 2017).

Pengaruh antara indikator-indikator dari laten eksogen faktor lingkungan (Y1) terhadap laten endogen keberlanjutan (Y2). Laten eksogen faktor lingkungan terdiri dari 5 indikator, diantaranya yaitu : pemberian pupuk (x11); pemberian insektisida (x12); pemangkasan ranting (x13); penyiangan rumput dan pembersihan sampah (x14); dan pemanenan (x15). Laten endogen keberlanjutan terdiri dari 2 indikator, yaitu penerimaan (Y11) dan pendapatan (Y12). Pengambilan data baik laten eksogen maupun endogen menggunakan data langsung dilapangan kemudian di skla menggunakan skala linkert. Skala Linkert menggunakan skala 1-4, dengan skoring 1 : Sangat Setuju; 2 : Setuju; 3: Tidak setuju; dan 4: sangat tidak setuju. Diagram jalur digambarkan pada Gambar 1.

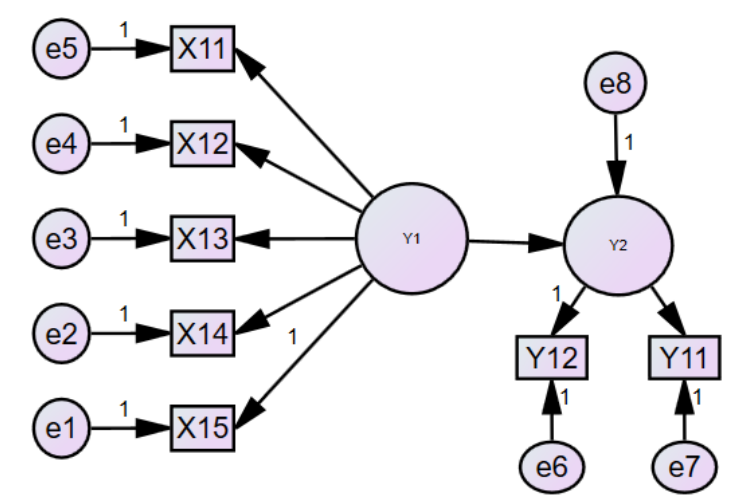

Gambar 1. Estimasi Struktur Model Penelitian

Keterangan :

$\begin{array}{ll}\text { Y1 } & \text { : Aspek Lingkungan } \\ \text { Y2 } & \text { : Keberlanjutan } \\ \text { X11 } & \text { : Pemberian Pupuk } \\ \text { X12 } & \text { : Pemberian Insektisida } \\ \text { X13 } & \text { : Pemangkasan ranting } \\ \text { X14 } & \text { : Penyiangan rumput dan pembersihan sampah } \\ \text { X15 } & \text { : Pemanenan } \\ \text { Y11 } & \text { : Penerimaan } \\ \text { Y12 } & \text { : Pendapatan } \\ \text { e1-e8 } & \text { : error }\end{array}$

Nilai x11 sampai x15 merupakan koefesien regresi yang sudah distandarisasi (standardized regression coefficient) yang menunjukkan jumlah perubahan dalam variabel dependen endogenous yang dihubungkan dengan perubahan (kenaikan atau penurunan). Di dalam penelitian ini nilai dalam koefesien jalur atau jumlah pengaruh setiap variabel faktor lingkungan 
diharapkan bernilai positif, yang berarti semakin besar nilai dari tiap indikator, maka semakin besar nilai yang diperoleh dalam variabel keberlanjutan.

\section{Hasil dan Pembahasan}

1. Uji Normalitas

Berdasarkan hasil uji normalitas variabel, nilai critical multivariate model yang diperoleh adalah 4,841. Menurut Ghozali, (2017) model dinyatakan telah memenuhi asumsi normalitas jika memiliki c.r multivariat dalam rentang $-2,58<z<2,58$. Nilai 4,841 belum masuk dalam data berdistribusi normal, maka langkah yang harus dilakukan yaitu dengan menggunakan teknik bootstrapping. Dari hasil bootstrapping didapatkan nilai p Bollen Stine adalah 0,473, yang memperoleh nilai $\mathrm{p}$ ketepatan model secara keseluruhan. Dengan menggunakan kriteria signifikansi konvensional $(\mathrm{p}=0,05)$ akan didapatkan bahwa nilai $\mathrm{p}$ yang dihasilkan oleh model adalah lebih dari 0,05 . Nilai 0,473>0,05, dengan demikian bisa simpulkan bahwa model yang dikembangkan didukung atau sesuai data.

2. Uji validitas

Pengukuran validitas konstruk penelitian dapat dilihat dari nilai faktor loadingnya. Faktor loading yang digunakan dalam uji validitas penelitian ini adalah $\geq 0.50$, sehingga item yang memiliki Faktor loading kurang dari $\geq 0.50$ dianggap tidak valid dan tidak diikutsertakan dalam pengukuran. Faktor loading lebih besar 0,30 dianggap memenuhi level minimal, Faktor loading 0.40 dianggap lebih baik dan sesuai dengan rules of thumb yang dipakai para peneliti, dan Faktor loading sama dengan atau lebih dari 0.50 dianggap signifikan (Hair et al., 2010). Hasil output Amos 24 dalam penelitian ini disajikan di Tabel 1.

Berdasar Tabel 1 dapat diketahui bahwa semua loading faktor tiap indikator nilainya lebih besar dari 0,50, itu artinya semua indikator dinyatakan valid dan evaluasi model bisa diterima.

Tabel 1. Data Hasil Uji Validitas Instrumen

\begin{tabular}{llcc}
\hline Item & Variabel & Loading Faktor $(\lambda)$ & Ket. \\
\hline X11 & : Pemberian Pupuk & 0,743 & Valid \\
X12 & : Pemberian Insektisida & 0,779 & Valid \\
X13 & : Pemangkasan ranting & 0,864 & Valid \\
X14 & : Penyiangan rumput dan pembersihan sampah & 0,917 & Valid \\
X15 & : Pemanenan & 0,866 & Valid \\
Y11 & : Penerimaan & 0,699 & Valid \\
Y22 & : Pendapatan & 0,656 & Valid \\
\hline
\end{tabular}

Sumber : Data Primer Diolah (2020)

3. Uji reliabilitas

Uji reliabilitas adalah sejauh mana hasil pengukuran dengan menggunakan objek yang sama, akan menghasilkan data yang sama. Uji reliabilitas dilakukan secara bersama-sama terhadap seluruh pernyataan (Sugiyono, 2017). Pengukuran reliabilitas pada penelitian ini menggunakan Construct Reliability (CR). Terdapat banyak juga penelitian yang menggunakan Cronbach alpha sebagai ukuran reliabilitas, namun menurut (Ghozali, 2017) Construct Reliability (CR) mampu memberikan reliabilitas yang lebih tinggi dibandingkan Cronbach alpha, sehingga penelitian ini menggunakan kriteria CR.

Construct Reliability $(\mathrm{CR}) \geq 0.70$ menunjukkan reliabilitas yang baik, sedangkan CR 0.60 0.70 dikatakan masih dapat diterima dengan syarat validitas indikator dalam model baik (Ghozali, 2017).

Tabel 2. Hasil Average Variance Extracted (AVE) dan Construct Reliability (CR)

\begin{tabular}{cccccc}
\hline \multirow{2}{*}{ Variabel } & Indikator & $\begin{array}{c}\text { Loading Faktor } \\
(\lambda)\end{array}$ & $\begin{array}{c}\text { Standar Loading } \\
\left(\lambda^{2}\right)\end{array}$ & Measuremen Error & CR \\
\hline \multirow{4}{*}{ Y1 } & X11 & 0,743 & 0,551 & 0,449 & \\
& $\mathrm{X} 12$ & 0,779 & 0,608 & 0,392 & 0,920 \\
& $\mathrm{X} 13$ & 0,864 & 0,746 & 0,254 & \\
\hline & $\mathrm{X} 14$ & 0,917 & 0,839 & 0,161 & \\
\hline
\end{tabular}

Sumber : Hasil Analisis Data (diolah), 2020

Berdasarkan Tabel 2 diketahui bahwa nilai CR sebesar 0,920. Itu artinya nilai tersebut diatas 0,70 maka semua konstruk dalam Diagram ini layak. 


\section{Analisis jalur (Path)}

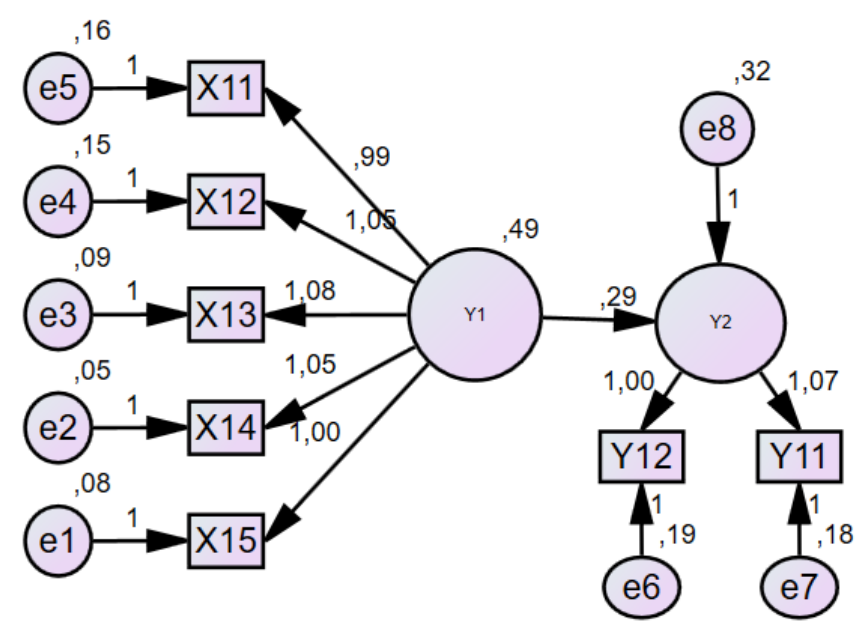

Gambar 2. Hasil Estimasi Diagram Jalur

Berdasarkan Gambar 2 menunjukkan koefisien terstandar satu variabel ke variabel lainnya. Koefisien terstandar ini nilainya sudah standar dari 0-1, sehingga peneliti bisa membandingkan mana yang lebih besar peranannya. Dari Gambar 2 dapat peneliti lihat, pengaruh faktor lingkungan ke keberlanjutan usahatani sebesar 0,29. Angka tersebut positif, sehingga dapat peneliti katakan bahwa faktor lingkungan mempengaruhi pendapatan usahatani di Kecamatan Limbangan Kabupaten Kendal.

Hasil yang didapat dari angka tersebut menunjukan semakin besar nilai faktor lingkungan, maka akan semakin berpengaruh positif terhadap keberlanjutan. Secara bersama-sama variabel Lingkungan yang indikatornya terdiri dari pemberian pupuk, pemberian insektisida, pemangkasan ranting, penyiangan rumput dan pembersiahan sampah, serta pemanenan berpengaruh nyata terhadap keberlanjutan usahatanu alpukat di Kecamatan Limbangan Kabupaten Kendal. Penelitian dari Susanti (2017) bahwa Keseluruhan variabel lingkungan merupakan faktor yang memiliki keterkaitan erat dengan upaya menyesuaian serta menjaga kondisi lingkungan sehingga tetap mendukung untuk keberhasilan dan keberlanjutan usaha.

Merujuk pada hasil analisis faktor konfirmatori pada variabel Keberlanjutan (Y2), dapat dilihat variabel faktor lingkungan memberikan gambaran bahwa pemberian pupuk, pemberian insektisida, pemangkasan ranting, penyiangan rumput dan pembersihan sampah serta pemanenan merupakan faktor lingkungan yang dapat mendukung terciptanya keberlanjutan pertanian.

Berdasarkan analisis Faktor (CFA) pada variabel faktor lingkungan (Y1), keberlanjutan usahatani merupakan konsep yang berkelanjutan dan didapat nilai koefisien tiap indikator sebagai berikut : pemberian pupuk $(\mathrm{x} 11=0,990)$; pemberian insektisida $(\mathrm{x} 12=1,050)$, pemangkasan ranting $(\mathrm{x} 13=1,080)$, penyiangan rumput dan pembersiahan sampah $(\mathrm{x} 14=1,050)$, serta pemanenan $(\mathrm{x} 15=1,000)$. Lima indikator tersebut terbukti valid dan reliable dalam mengukur faktor lingkungan sebagai variabel di dalam penelitian.

Tabel 3. Standardized Regression Weights

\begin{tabular}{lccccc}
\hline Variabel & & & Estimate & Koefisien & P \\
\hline Keberlanjutan & $<---$ & Faktor Lingkungan & 0,331 & 0,290 & $* * *$ \\
Penyiangan rumput dan & $<---$ & Faktor Lingkungan & 0,958 & 1,050 & $* * *$ \\
Pembersiahan sampah & $<---$ & Faktor Lingkungan & 0,930 & 1,080 & $* * *$ \\
Pemangkasan ranting & $<---$ & Faktor Lingkungan & 0,883 & 1,050 & $* * *$ \\
Pemberian insektisida & $<--$ & Keberlanjutan & 0,810 & 1,070 & $* * *$ \\
Penerimaan & $<---$ & Keberlanjutan & 0,836 & 1,000 & $* * *$ \\
Pendapatan & $<---$ & Faktor Lingkungan & 0,862 & 0,990 & $* * *$ \\
Pemberian pupuk & $<---$ & Faktor Lingkungan & 0,930 & 1,000 & $* * *$ \\
Pemanenan &
\end{tabular}

Sumber : Data Primer Diolah, (2020);Keterangan: *** : signifikan pada a 0,01 
Pemupukan adalah salah satu kegiatan yang harus dilakukan dalam membudidayakan suatu tanaman (Karbaju, 2017). Tabel 3 menunjukkan pemberian pupuk (x11) mempunyai nilai koefisien 0,990 hal ini menunjukkan secara signifikan indikator pemberian pupuk berpengaruh langsung terhadap faktor lingkungan dan keberlanjutan usahatani alpukat. Hasil analisis pada Standardized Regression Weights menunjukan Pemberian pupuk berpengaruh langsung terhadap Faktor Lingkungan dengan koefisien regresi terstandar 0,862. Pemberian pupuk yang tepat akan menyebabkan tanaman alpukat tumbuh dengan baik. Ini akan berdampak pada kondisi tanah. Dimana kondisi tanah yang subur dan baik, maka lingkungan juga akan ikut baik pula. Adanya kondisi tanah yang baik maka akan mempengaruhi produksi, semakin produksinya baik, maka keberlanjutan dalam menjalankan usahatani akan berlanjut.

Penelitian yang dilakukan Adelina (2016) menyatakan Pupuk berpengaruh nyata terhadap produksi tanaman. Asumsi bahwa penggunaan pupuk merupakan salah satu cara untuk meningkatkan kualitas maupun kuantitas produk tanaman yang diperoleh. Penggunaan pupuk yang efektif dan efisien tersebut, maka akan diperoleh kualitas tanah sebagai media tanam akan memberikan zat-zat yang dibutuhkan oleh tanaman untuk menghasilkan produksi yang optimal. Produksi yang baik dipengaruhi oleh kondisi kesuburan tanah.

Indikator pembentuk faktor lingkungan adalah insektisida. Indikator ini memiliki koefisien 1,05 , artinya indikator pemberian insektisida berpengaruh langsung terhadap variabel faktor lingkungan dan keberlanjutan usahatani alpukat. berpengaruh langsung terhadap faktor lingkungan dan keberlanjutan usahatani alpukat. Hasil analisis pada Standardized Regression Weights menunjukan Pemberian Insektisida berperan langsung terhadap faktor lingkungan dengan koefisien regresi terstandar 0,883.

Susanti (2015) dalam penelitannya menyatakan pestisida dilaporkan dapat menurunkan kesuburan tanah dan proses biologi di dalam lingkungan tanah. Hasil penelitian memperlihatkan bahwa penggunaan pestisida dan pengelolaan air selama dua periode tanam, tidak memperlihatkan pengaruh buruk terhadap hara-hara tanah. Pestisida tidak menjadi penyumbang terhadap kenaikan emisi $\mathrm{CO}_{2}$ dan $\mathrm{CH}_{4}$ dan tidak menurunkan kualitas lingkungan di lahan. Hasil penelitian ini menunjukkan ketika petani alpukat memberikan insektisida, akan mempunyai pengaruh nyata terhadap pertumbuhan dari pohon alpukat itu sendiri, bahkan bisa ke pohon lain yang ada disekitarnya. Pemberian insektisida yang tepat akan menjadikan lingkungan yang baik pula.

Indikator ke-3, yakni pemangkasan ranting. Koefisien yang didapatkan dari penelitian indikator pemangkasan ranting sebesar 1,08 , hal ini menunjukkan secara signifikan indikator pemangkasan ranting berpengaruh langsung terhadap faktor lingkungan dan keberlanjutan usahatani alpukat. Berdasar hasil Standardized Regression Weights Pemangkasan ranting berperan langsung terhadap keberlanjutan usahatani alpukat dengan koefisien regresi terstandar 0,930. Alasan mengenai hal tersebut dikarenakan keberadaan tanaman yang berada di wilayah pemukiman penduduk akan mempengaruhi ketika ranting sudah mengganggu lingkungan sekitar. Dampak lain dari pemangkasan terhadap lingkungan yaitu mencegah terjadinya iklim mikro. Iklim mikro adalah sarang berkembangnya penyakit dan hama pada daerah ranting dan cabang yang rimbun. Pemangkasan pada cabang yang rimbun akan dapat mencegah serangan organisme penganggu tanaman. Adanya organisme pengganggu tanaman tersebut akan berpengaruh terhadap produksi tanaman alpukat itu sendiri.

Pemangkasan ranting yang tepat akan menghasilkan produksi yang baik pula. Hasil tersebut sesuai dengan penelitian Hariyadi (2011) yang menyebutkan Pemangkasan batang menghasilkan laju fotosintesis tertinggi sehingga meningkatkan jumlah kapsul per tanaman, jumlah biji per tanaman, dan bobot kering biji per tanaman.

Indikator ke-4 yaitu Penyiangan rumput dan pembersiahan sampah (x14). Penyiangan rumput dan pembersihan sampah merupakan indikator penting dalam menciptakan lingkungan yang bersih dan bebas dari gulma. Indikator ini mempunyai nilai koefisien 1,05. Berdasarkan hasil Standardized Regression Weights, penyiangan rumput dan pembersihan sampah berpengaruh terhadap faktor lingkungan dengan nilai koefisien regresi terstandar 0,958. Nilai tersebut berarti menunjukkan secara signifikan indikator Penyiangan rumput dan pembersiahan sampah berpengaruh langsung terhadap faktor lingkungan.

Lingkungan disekitar tanaman yang bersih dari sampah dan rumput liar (gulma) akan mempengaruhi produksi tanaman alpukat. Hasil penelitan Christia (2016) menyatakan gulma menurunkan jumlah daun 9 MST, bobot kering tajuk tanaman. Kehadiran gulma tersebut pada kerapatan 10 gulma/m² sudah mampu menekan tinggi tanaman 9 MST dan bobot kering akar tanaman. Antara jenis dan kerapatan gulma saling berpengaruh, sehingga dapat menekan tinggi tanaman sebesar 3 MST. Dari penelitan tersebut memperkuat bahwa pengaruh pembersihan sampah dan gulma akan mempengaruhi lingkungan dan hasil produksi alpukat. 
Indikator ke-5 dalam pembentukan variabel lingkungan yaitu pemanenan (X15). Pada penelitian ini, pemanenan yaitu proses dalam memanen buah alpukat. Hasil yang didapat mendapatkan nilai koefisien sebesar 1,00. Hasil Standardized Regression Weights, pemanenan berpengaruh terhadap faktor lingkungan dengan nilai koefisien regresi terstandar 0,930. Nilai tersebut menunjukkan secara signifikan indikator pemanenan berpengaruh langsung terhadap faktor lingkungan. Pemanenan mempengaruhi lingkungan dikarenakan cara dan proses pemanenan harus secara benar dan tepat. Benar dalam arti harus mengikuti kaidah sesuai prosedur, diantaranya tidak merusak tanaman itu sendiri, tidak merusak tanaman di sekitarnya, dan tidak mengganggu lingkungan yang ada di sekitar penduduk (kabel listrik, genteng, dan kebersihan sekitar). Tepat berarti pemanenan sesuai waktu panen yang tepat, dimana hanya memanen buah sudah cukup tua dan tidak merusak buah yang masih muda.

Endah (2020) menyatakan faktor-faktor yang menentukan saat panen diantaranya sifat varietas, hari tanam/hari berbunga dan faktor lingkungan selama musim tanam. Panen yang benar dan tepat, maka akan memperkecil resiko dari kerusakan tanaman dan buah, sehingga akan mempengaruhi dari pendapatan. Pendapatan yang baik akan diimbangi dengan keberlanjutan usahatani itu sendiri. Artinya panen berpengaruh terhadap lingkungan dan keberlanjutan dari usahatani alpukat.

\section{Simpulan}

Dari hasil analisis yang telah dilakukan, maka kesimpulan dari penelitian ini adalah Faktor lingkungan berpengaruh terhadap keberlanjutan usahatani alpukat. Semua indikator dalam konstruk eksogen yang terdiri dari pemberian pupuk (x11); pemberian insektisida (x12); pemangkasan ranting (x13); penyiangan rumput dan pembersihan sampah (x14); serta pemanenan (x15) memberi pengaruh terhadap laten eksogen itu sendiri. Dari hasil ini, petani bisa memperhatikan indikator apa saja yang mempengaruhi keberlanjutan agar keberlanjutan tercipta dengan baik. Semua indikator tersebut berpengaruh dengan masing-masing nilai koefisiennyan dari indikator pemberian pupuk $(\mathrm{x} 11=0,990)$; pemberian insektisida $(\mathrm{x} 12=1,050)$, pemangkasan ranting $(\mathrm{x} 13=1,080)$, penyiangan rumput dan pembersiahan sampah $(\mathrm{x} 14=1,050)$, serta pemanenan $(\mathrm{x} 15=1,000)$. Berdasar data tersebut dapat disimpulkan bahwa faktor lingkungan yang ada di daerah penelitian mempunyai pengaruh terhadap keberlanjutan usahatani alpukat.

\section{Pustaka}

BPS Kendal. 2020. Kabupaten Kendal Dalam Angka 2020. Badan Pusat Statistik Kendal. Kendal

Christia, Agatha. 2016. Pengaruh Jenis Dan Tingkat Kerapatan Gulma Terhadap Pertumbuhan Dan Produksi Kedelai (Glycine Max [L]. Merr). J. Agrotek Tropika. 4(1): 22-28.

Endah, Budi Irawati. 2020. Kelompok Faktor Pasca Panen. Universitas Pembangunan Nasional Veteran.Yogyakarta.

Ghozali, I. 2017. Model Persamaan Struktural Konsep dan Aplikasi dengan Program AMOS 24.0. Badan Penerbit Universitas Diponegoro. Semarang.

Hariyadi, Purwoko B, Ince R. 2011. Pengaruh Pemangkasan Batang dan Cabang Primer terhadap Laju Fotosintesisdan Produksi Jarak Pagar (Jatropha curcas L.). J. Agron. Indonesia 39 (3) : $205-209$

Hair, Joseph F., Black, Bill, Babin, Barry, Anderson, Rolph E.,. (2010). Multivariate Data Analysis (Sixth Edit). Prentice Hall: Upper Saddle River: New Jersey

Karbaju, Alfrida., Adeline Norawati H. 2017. Analisis Pendapatan Usahatani Jagung pada Kelompok Tani Oelbubuk di Desa Oeolo Kecamatan Musi Kabupaten Timor Tengah Utara. Agrimor 2 (4): 63-64

Kementan. 2019. Ekspor Holtikultura Naik 12 Persen di 2018, Diakses dari https://www.pertanian.go.id/home/?show=news\&act=view\&id=3545. Jakarta

Purnomo, R.A, Riawan, La Ode Sugianto. 2017. Studi Kelayakan Bisnis. Unmuh Ponorogo Press. Ponorogo.

Sani, Achmad \& Vivin Maharani. 2013. Metodologi Penelitian Manajemen Sumber Daya Manusia (Teori, Kuisioner dan Analisis Data). UIN MALIKI Press. Cetakan Ke-2. Malang

Sugiyono. 2017. Metode Penelitian Kuantitatif, Kualitatif, dan R\&D. Alfabeta. Bandung

Susanti. 2017. Analisis Indeks Keberlanjutan Usaha Pembesaran Lobster Di Pulau Lombok Provinsi Nusa Tenggara Barat. AGRICORE 2 (1): 205-290

Sutrisno, B. 2013. Kerancuan Yuridis Kewenangan Perlindungan dan Pengelolaan Lingkungan Hidup dalam Perspektif Otonomi Daerah. Jurnal Ilmu Hukum DIH. 9(17): 19-34.

Usboko, Adelina M. 2016. Faktor Sosial Ekonomi yang Mempengaruhi Produksi Usahatani Sayuran Sawi di Kelompok Tani Mitra Timor . Agrimor 1 (3) 60-62 